the interests of justice, 54 and (2) that the transferee forum be one in which the action could have originally been brought. 55

A serious objection to the section 1404(a) solution is the problem of the choice of law to be applied by the transferee forum. ${ }^{56}$ For example, if a forumshopping corporation, motivated by considerations of the statute of limitations, were to choose a forum where the statute had not run and then was transferred to a forum where it had, which statute of limitations should the transferee forum apply? 57 It has been suggested that the transferee forum should apply the statute of the transferor forum, or alternatively, that the defendant should have to waive the defense in order to get the transfer. ${ }^{58}$ In either case the corporation would get the benefits of its forum shopping and at the same time share in the benefits of trial in the forum conveniens. Such a result would be more likely to encourage forum shopping, rather than to put an end to it.

It is submitted that section 1391 (c) is not a definition of corporate residence as the Freiday-Hadden interpretation assumes. Both the legislative history and an analysis of section 1391 indicate that section 1391(c) is a separate venue provision to be used in actions in which the defendant is a corporation. So treated, section 1391(c) is not applicable to corporate plaintiffs.

54 This language may well require that the transferee forum be the forum conveniens. Cf. Gulf Oil Corp. v. Gilbert, 330 U.S. 501 (1947). If so, there could be no transfer in those cases where the Freiday-Hadden interpretation had not made that forum available.

55 This means where it could have been brought with proper jurisdiction and proper venue. The defendant may not get a transfer if either jurisdiction or venue would not have been proper without his waiver. Hoffman v. Blaski, 363 U.S. 335 (1960). But see Continental Grain Co. v. Barge FBL-585, 364 U.S. 19 (1960).

56 For a discussion of the problem, see Currie, Change of Venue and the Confict of Laws, 22 U. CHI. L. REv. 405 (1955); Currie, Change of Venue and the Conflict of Laws: A Retraction, 27 U. CHI. L. REv. 341 (1960).

57 This was the question posed in Headrick v. Atchison, T. \& S.F. Ry., 182 F.2d 305 (10th Cir. 1950).

58 Id. at 308-09.

\title{
PERCENTAGE DEPLETION AND THE INTEGRATED MINER-MANUFACTURER
}

Two different forums have recently re-examined and redefined the base for the percentage depletion deduction. ${ }^{1}$ The United States Supreme Court restricted the application of the controversial phrase, "ordinary treatment proc-

1 The percentage depletion deduction has been one of the most publicized and controversial deductions in our present tax system. See generally Goulette, Depletion for Tax Purposes: A Condensed Picture of How it Works in Mining, 4 J. TAXATION 258 (1956); Macleod, Percentage Depletion Controversy, 99 J. Accountancy 40 (1955). See also Note, 20 U. PITT. L. Rev. 155 (1958); Note, 28 Geo. Wash. L. Rev. 666 (1960); Note, 108 U. PA. L. Rev. 758 (1960); Tax Notes, 46 A.B.A.J. 1136 (1960). 
esses." 2 Congress replaced the general "ordinary treatment processes" by listing particular processes. ${ }^{3}$ In both forums the Commissioner has prevailed. But the implications of each victory are difficult to discern, and the Commissioner may yet regret the results of his vigorous arguments.

The depletion deduction has been justified on two grounds: (1) it enables mine owners to recover capital exhausted in the extraction of minerals, ${ }^{4}$ and (2) it encourages private capital to develop natural resources despite the risk involved.5 The percentage method of computing depletion was introduced to simplify the procedure for calculating the deduction. 6 However, it may be that the susceptibility of this method to abuse outweighs whatever merit its vaunted simplicity may have. Furthermore, the simplicity may be an illusion, for the computation of the proper base for depletion may be equally as complicated as the methods which it replaced.

The percentage depletion deduction bears no relationship to the cost of the property mined and may in fact greatly exceed the cost. 7 The taxpayer may deduct a percentage of the "gross income from the property." The appropriate percentage for each mineral is defined by the Code. 8 The deduction may not exceed fifty per cent of the "taxable income from the property." Section 61310

2 United States v. Cannelton Sewer Pipe Co., 364 U.S. 76 (1960).

3 P. L. 86-564, § 302(a)-(b), effective Jan. 1, 1961 amending INT. Rev. CODE of 1954 $\S 613(\mathrm{~b})$. Some problems raised by this amendment are discussed in the text at notes $36-38$ infra.

4 See United States v. Ludey, 274 U.S. 295, 302-03 (1927). "In essence, the deduction for depletion does not differ from the deduction for depreciation." However, depletion and depreciation do differ in that "depletion is applicable to wasting assets-to the exhaustion of natural resources, not of property used in business." Choate v. Comm'r, 324 U.S. 1, 3 (1945). Another major difference between the deductions is the rate of recovery. The depreciation rate on property is determined by the general life expectancy of such property; the depletion rate is applied to the life of the depletable property under a unit-of-income method. See United States v. Dakota-Montana Oil Co., 288 U.S. 459 (1933).

5 See White \& Brainerd, Percentage Depletion of Minerals-A Costly Study in Definitions, 34 TAXES 97, 98 (1956); United States v. Cannelton Sewer Pipe Co., 364 U.S. 76, 81 (1960).

6 Other methods provided were cost and discovery depletion. See 4 MERTENs, LAw of FederAL INCOME TAXATION $\S \S 24.29-24.36$ (1960). For taxable years after December 31, 1953 , cost depletion is the only alternative to percentage depletion. See Hobbert \& Donaldson, Percentage Depletion for Minerals, 37 TAXES 477, 479-80 (1959); H.R. REP. No. 356, 69 th Cong., 1st Sess. 31 (1939), where it was said that "the administration of the discovery provision of existing law in the case of oil and gas wells has been very difficult because of the discovery valuation that had to be made in the case of each discovered well. In the interest of simplicity and certainty in administration the Senate amendment provides for a percentage depletion method of calculation."

${ }^{7}$ See Commissioner v. Southwest Exploration Co., 350 U.S. 308, 312 (1956).

8 INT. Rev. CODE OF 1954, § 613(b).

9 INT. REv. CODE OF 1954, $\S 613(\mathrm{a})$. The fifty per cent of "taxable income" limitation originally read "net income from the property." 53 Stat. 45 (1939). However, the phrases are identical in meaning for depletion purposes. H. R. REP. No. 1337, 83rd Cong., 2d Sess. A184. Since the percentage depletion deduction is limited to $50 \%$ of the taxable income from the property (without allowance for depletion), no deduction is allowable where the income 
of the Code defines "gross income from the property" to be the "gross income from mining." "Mining" is defined to include extraction and "the ordinary treatment processes 11 ... applied . . . to obtain the commercially marketable mineral product or products." 12

The scope of the last-quoted phrase has been the subject of protracted litigation. Integrated miner-manufacturers, interested in obtaining large deductions each year, have sought to apply the depletion percentage to the value of their mineral products after substantial treatment and finishing processes.13 The nonintegrated miner, by definition, cannot expand his depletion base by postponement, and he must be content with a smaller deduction. To prevent the inequitable operation of percentage depletion, the Commissioner has sought to limit the deduction first by contesting the kind of treatment processes allowable and later by attacking the taxpayers' determination of the "commercially marketable product."

from the property is zero. James Petroleum Corp., 24 T.C. 509 (1955), aff'd, 238 F.2d 678 (2d Cir. 1956).

10 This comment will refer to the applicable sections of the 1954 Code, but the provisions are, for all material purposes, the same as the applicable sections in the 1939 Code.

11 The Code lists five categories of minerals and ores. INT. REV. CODE OF 1954, \$ 613(c)(4). The first category enumerates those "ordinary treatment processes" permissible in the mining of coal; the second refers to sulphur; the third refers to certain minerals and those "minerals which are customarily sold in the form of a crude mineral product"; the fourth refers to certain ores and those ores "which are not customarily sold in the form of the crude mineral product"; and the fifth category refers to talc and related minerals. The fifth category was not present in the 1939 Code. However, the listed processes are not conclusive. It has been held that "the lists of processes are in no way exclusive, even as to the ores and minerals covered." Townsend v. Hitchcock Corp., 232 F.2d 444, 446 (4th Cir. 1956). See Dragon Cement Co. v. United States, 244 F.2d 513 (1st Cir. 1957). See generally Tax Notes, supra note 1.

12 The percentage depletion deduction provision was first enacted in 1926. It was intended to provide a simplified method of computing depletion for oil and gas wells. The percentage was to be applied to the "gross income from the property." However, that phrase was not defined in the Code. See Treas. Reg. 74, \$\$ 221(i) \& 224 (1929). Thereafter, the 1932 Code extended the percentage depletion deduction to metal, coal and sulphur mines. The percentage depletion deduction for these minerals was computed in the same manner as for oil and gas wells. See Preliminary Report on Depletion, Staff Report to the Joint Committee on Internal Revenue Taxation, Appendix XXXI (1930) (The Shepard Report). For a discussion of this report see United States v. Cannelton Sewer Pipe Co., 364 U.S. 76 (1960). In 1933 the Treasury issued Regulation 77, which defined the term "gross income from the property." Finally, in 1943, Congress adopted the Treasury's definition. 58 Stat. 45 (1944). See the Cannelton case, supra, at 85. From 1943 to 1959 the section has remained basically the same except for the addition of other minerals and ores. For an exhaustive discussion of the section's legislative history see Brief for Petitioner, p. 36, United States v. Cannelton Sewer Pipe Co., supra.

13 The question is how much more than the cost of extraction is includable in the depletion base. If the taxpayer in United States v. Cannelton Sewer Pipe Co., 364 U.S. 76 (1960), had used the value of its raw mineral after extraction processes, its deduction would have been approximately 20 \& per ton. If the same taxpayer had used the value of its end product, alleged by it to be its first commercially marketable product, its deduction would have been $\$ 4$ per ton. 


\section{The Cheroker Case}

In Cherokee Brick and Tile Co. v. United States 14 an integrated minermanufacturer of bricks and other clay products sought to apply the depletion percentage to the value of its finished products. ${ }^{15}$ Between the extraction of the clay and the completion of the production process, firing and other finishing processes had been applied. It was not denied that these were "manufacturing processes." The taxpayer declared that it had no commercial market for its products until after application of the costly finishing processes; it contended, therefore, that all processes employed to reach that stage of production must be "ordinary treatment processes," includable by statute in the depletion base. The Commissioner challenged this interpretation of the statute. Stipulating that no commercial market existed for the taxpayer's products before the finished stage, the Commissioner argued that no manufacturing processes could ever be includable in the depletion base. The district court rejected the Commissioner's argument and entered judgment for the taxpayer; ${ }^{16}$ the Fifth Circuit Court of Appeals affirmed.17

The court glossed Section 613 by reading in "first" before "commercially marketable product."18 It then held that all processes necessary to reach the first commercially marketable product are, by the statutory definition, ordinary treatment processes. The character of the processes was held to be irrelevant. 19

\section{The CANnelton CASe In the Lower Courts}

The Cherokee case did not explain how to determine at what stage a mineral is commercially marketable. Because the Commissioner had stipulated that

14218 F.2d 424 (5th Cir. 1955).

15 Contrary to the position of the Internal Revenue Service, taxpayers have been allowed by the courts to use separate depletion bases for products sold in different forms. Sparta Ceramic Co. v. United States, 168 F. Supp. 401 (S.D. Ohio 1958); Richland Shale Prod. Co. v. United States, 168 F. Supp. 73 (E.D.S.C. 1958).

16122 F. Supp. 59 (M.D. Ga. 1954).

17218 F.2d 424 (5th Cir. 1955).

18 The court had precedent for its gloss. See International Talc. v. United States, 15 T.C. 981 (1950); Black Mountain Corp. v. United States, 21 T.C. 746 (1954).

19 The district court declared: "Had Congress intended by the use of the word mining to exclude all manufacturing processes, it would have been a simple matter to do so. Congress made no such distinction." 122 F. Supp. at 63.

Cherokee was widely followed. Townsend v. Hitchcock Corp., 232 F.2d 444 (4th Cir. 1956); Dragon Cement Co. v. United States, 244 F.2d 513 (1st Cir. 1957), cert. denied, 355 U.S. 833 (1957); United States v. Merry Bros. Brick \& Tile Co., 242 F.2d 708 (5th Cir. 1957), cert. denied, 355 U.S. 824 (1957); Wagner Quarries Co. v. United States, 154 F. Supp. 655 (N.D. Ohio 1957), aff'd per curiam, 260 F.2d 907 (6th Cir. 1958). Denial of certiorati by the Supreme Court in Dragon and Merry Bros. persuaded the Internal Revenue Service to conform its regulations to the Cherokee rule. See Treas. Reg. 62 (1957). Several months later, however, the Treasury began its campaign to amend the statute. Hearings Before the House Committee on Ways and Means on General Revenue Revision, 85th Cong., 2d Sess., pt. 1, 1097-98 (1958). 
the taxpayer's clay was not commercially marketable until fired into bricks, the court did not have that issue before it. In his next attempt to restrict the scope of the deduction, the Commissioner made no stipulation. He challenged the taxpayer's assertion that no commercial market for its mineral existed before application of the costly finishing processes.

In United States v. Cannelton Sewer Pipe Co., ${ }^{20}$ a suit to recover alleged excessive payment, an integrated miner-manufacturer of sewer pipe argued that "the processes by which it produced vitrified sewer pipe and related products from its fire clay and shale qualify as 'ordinary treatment processes ... since it had no market for its minerals in the crude form and such processes were of necessity applied by it in order to obtain the first commercially marketable products." 21 In litigation, the Commissioner maintained that in the tax year in question "there was an existing substantial market for raw clay . . . ; and that, in light of this fact, raw fire clay and shale were taxpayer's first commercially marketable products." 22 It was his conclusion that only those treatment processes which were utilized in reaching these marketable products were includable in the taxpayer's depletion base.

The facts marshalled by the Commissioner persuaded both the district court and the circuit court that a substantial market for fire clay and shale had indeed existed. ${ }^{23}$ But because Cannelton could not have sold its raw minerals in this market at a profit, the courts refused to reach the Commissioner's conclusion. The courts found inherent in the phrase "commercially marketable" a requirement of economic feasibility. ${ }^{24}$ As a result, the taxpayer was permitted to apply the depletion percentage to its finished products, which were the first products that it could have marketed at a profit. 25

\section{The Alternative Tests}

Upon petition by the Commissioner, the Supreme Court granted certiorari.26 The issue to be resolved by the Court was evaluation of the respective tests advanced as interpretations of the phrase "commercially marketable" in section 613. The Commissioner urged acceptance of an "industry-wide" test; and the taxpayer, supported by the lower federal courts, relied upon a "profitability" test.

The Commissioner contended that there is only one depletable or first com-

20364 U.S. 76 (1960), reversing 268 F.2d 334 (7th Cir. 1959). The opinion of the district court is not reported.

21268 F.2d at 336.

23 Ibid.

22 Ibid.

24 Id. at 338.

25 Accord, Bookwalter v. Centropolis Crusher Co., 272 F.2d 391 (8th Cir. 1959); Commissioner v. Iowa Limestone Co., 269 F.2d 398 (8th Cir. 1959); Standard Clay Mfg. Co. v. United States, 176 F. Supp. 590 (W.D. Pa. 1959); Sparta Ceramic Co. v. United States, 168 F. Supp. 401 (N.D. Ohio 1958); Riverton Lime \& Stone Co., 28 T.C. 446 (19S7).

26361 U.S. 923 (1959). 
mercially marketable product from each mineral. He sought to limit the treatment processes includable in calculating the depletion base to those processes which would be necessary for the taxpayer to produce the representative product in its mineral industry. The value of the representative product, after the taxpayer had applied processes to arrive at that product, would constitute a constructive gross income for calculation of the depletion deduction. To determine the representative product for each mineral industry, the Commissioner would study each industry nationwide and discover at what stage each mineral is marketable with the least processing. 27 Whether the taxpayer could sell the representative product at a profit would be irrelevant. Similarly, whether the taxpayer actually produced the representative product in its operations would be irrelevant.

The profitability test, urged by the taxpayer, was based on no external, constructive standard. It would vary from taxpayer to taxpayer. Each minermanufacturer would determine at what stage in its operations it could sell its product at a profit. All processes necessary to transform the raw mineral into the first "profitable" stage would be includable in calculating the depletion base. The standard practice throughout the industry would be irrelevant. Similarly, under this test, the mere existence of a market, without the prospect of profit, would be irrelevant.

The profitability test would pose complex problems of administration for the Internal Revenue Service. 28 The Service could rely on neither the sale price of a taxpayer's finished product nor the uniform cut-off point made possible by use of a representative product. It would have (1) to determine the cost curve for each miner-manufacturer, and (2) to canvass all markets in each mineral industry. It would then limit the depletion base for each taxpayer to the value of its product at the first point at which themarket price exceeded the taxpayer's costs plus a "reasonable" profit.

Furthermore, the profitability test might place nonintegrated miners at a competitive disadvantage. The integrated miner-manufacturer would still be able to enlarge his depletion base and secure tax benefits not available to the nonintegrated miner. Such a result cannot be reconciled with the policy of depletion as compensation for the exhaustion of mineral reserve, rather than as a method for writing off the costs of finishing processes. 29

Finally, the profitability test might discriminate among integrated minermanufacturers. The longer that first profitability can be postponed, the greater is the depletion base. Therefore, the more inefficient manufacturer might obtain an advantage over his more efficient competitor. Thus, the profitability test might encourage inefficient vertical integration. ${ }^{30}$

27 See also the argument made by the Commissioner in Commissioner v. Iowa Limestone Co., 269 F.2d 398 (8th Cir. 1959).

28 The problems of administering the Commissioner's test are discussed in the text infra at p. 128.

${ }^{29}$ See text supra at note 4.

${ }^{30}$ See Tax Notes, supra note 1 , at 1140. 


\section{The Cannelton Case In the Supreme Court}

The Supreme Court, confronted by the alternative tests, held that the taxpayer's "gross income from mining . . . is the value of its raw fire clay and shale, after the application of the ordinary treatment processes normally applied by nonintegrated miners engaged in the recovery of those minerals." 31 The Court rejected the profitability test ${ }^{32}$ and, relying exclusively upon legislative history, apparently approved the Commissioner's industry-wide test. ${ }^{33}$ Scrutiny of the opinion, however, reveals some unanswered questions.

The Commissioner may reasonably doubt whether the Court has fully adopted his industry-wide test. By concentrating upon the lower courts' findings of a substantial market for the taxpayer's raw minerals in Indiana, the local region, the Court may have shifted the scope of the test from nationwide to region-wide. ${ }^{34}$ If the test is to be based on representative production in each

31 United States v. Cannelton Sewer Pipe Co., 364 U.S. 76, 89 (1960). (Emphasis added.)

32 The Court states that proof by the Commissioner of similar sales made in the same two-state area is significant not because it reveals an ability to sell profitably-which respondent could not do-but because the substantial tonnage being sold in a raw state provides conclusive proof that, when extracted from the mine, the fire clay and shale are in such a state that they are ready for industrial use or consumption. . . It would be strange, indeed, to ascribe to the Congress an intent to permit each miner to adopt processes peculiar to his individual operations." 364 U.S. at 88.

${ }^{33}$ The Court stated that "Congress intended to grant miners a depletion allowance based on the constructive income from the raw mineral product if marketable in that form, and not on the value of the finished articles." 364 U.S. at 86. (Emphasis added.)

In 1926 Congress passed the first percentage depletion provision, supra note 12, which provided for a $271 / 2 \%$ deduction based on the "gross income from the property" for gas and oil wells. The phrase, "gross income from the property," was defined so as to exclude integrated manufacturing processes from the depletion base. Treas. Reg. 74, § 221(i) (1929). The regulations said that "if the oil and gas are not sold on the property, but are manufactured ... into a refined product . . . then the gross income shall be assumed to be equivalent to the market or field price of the oil and gas before transportation and conversion." Ibid. This ruling was approved by the courts. Consumers Natural Gas Co. v. Commissioner, 78 F.2d 161, 162 (2d Cir. 1934), cert. denied, 296 U.S. 634 (1935). Thus, it seems clear that at that time the percentage depletion deduction was to be determined by reference to a constructive gross income if the taxpayer was an integrated producer.

In 1932 the percentage depletion method of calculation was extended to metal, coal and sulphur mines, and the depletion base was to be determined in the same fashion as for oil and gas wells. See Hearings Before the House Committee on Ways and Means on Revenue Revision, 69th-70th Cong. 510 (1927-28). The treasury regulations promulgated under the 1932 Act reflected this similar treatment. Treas. Reg. 77, § 221(g) (1933). Those regulations restricted the producer to the ordinary treatment processes necessary to the production of the particular mineral and precluded from inclusion in that base advance processes which were utilized by integrated miners. Thus, the integrated metal, coal and sulphur miners were required to determine their depletion base by reference to a constructive gross income.

The 1943 statutory definition of "gross income from mining" was a codification of the prior regulations. 53 Stat. 45 (1938), INT. Rev. CODE OF 1939, \$114(b)(4). The Code provisions had remained substantially the same until 1960 when the section was drastically changed. See text at note 3 supra.

34 The Court stated that "three-fifths of the fire clay produced in Indiana in 1951 was sold in its raw state" and that a "substantial market" for the taxpayer's raw material existed in Indiana. 364 U.S. at 79. The brief for the United States offered evidence of substantial sales all over the country as well as in Indiana. Brief for the United States at page 4. 
region, inequitable consequences may ensue. A miner-manufacturer in a region where all miners of the mineral which it produces are fully integrated will not have a "commercially marketable" product until the end of its finishing operations. A miner-manufacturer in a region which contains some nonintegrated miners of its mineral will have a "commercially marketable" product when it has reached the stage at which the nonintegrated miners market the mineral. It seems difficult to justify competitive differences caused by different depletion bases when these differences arise merely because of accidental location.

Conversely, the miner-manufacturer may doubt the endurance of the rule in the Cherokee case. Although the Court did not have before it the question presented in that case, the Court did state that the percentage depletion deduction "is an allowance for the exhaustion of capital assets" and "not a subsidy to manufacturers or the high-cost mine operator." 35 To the extent that minermanufacturers recover a percentage of their manufacturing costs under the Cherokee rule, the underlying justification for the depletion deduction is absent. Whether the Commissioner will again seek exclusion from the depletion base of all manufacturing costs remains uncertain.

The representative-product test, whether industry-wide or local, presents complex administrative problems. In the past mining companies have been able to compute the depletion deduction without reference to the operations of other mining companies. The burden of proof in suits challenging deficiencies levied by the Commissioner has been met by production of the miner's own records. ${ }^{36}$ The representative-product test, however, requires reference to norms. The miners will have to depend upon the Internal Revenue Service to supply the all-important determination of the representative product for each mineral industry. Rebuttal of this determination will be extremely difficult; and the self-executing character of tax reporting will be decreased.

Neither the Treasury nor the Supreme Court has stated whether the representative product is to be determined annually or otherwise. A shift toward integration of an industry between one tax year and the next would pose a troublesome problem: Is the standard to be set by the newly-integrated miner or by the no longer existing nonintegrated miner? If the newly-integrated miner sets the standard, then the drive toward total integration would be intensified, and the deduction would be abused. If the no longer existing nonintegrated miner continues to set the standard, then the law fails to recognize the ever-changing character of the economic structure of American industry.

The representative-product test, whether nation-wide or local, forces miners to establish a constructive gross income for calculation of the depletion deduc-

35 United States v. Cannelton Sewer Pipe Co., 364 U.S. 76, 77 (1960).

${ }^{36}$ The taxpayer has the burden of showing that a disallowance by the Commissioner is incorrect. Reinecke v. Spaulding, 280 U.S. 227 (1930). 
tion. It may also force them to establish a constructive taxable income for calculation of the fifty percent ceiling on the depletion deduction. ${ }^{37}$ Unless the second fiction is required, miners whose deduction is presently limited by the fifty per cent ceiling under the profitability test may not be effectively restricted by the more rigorous representative-product test. Even with the smaller base which the new test may require, the figure arrived at when percentage is applied to base for these miners may still exceed the allowable fifty per cent of actual taxable income; and unless taxable income is also made constructive the size of the allowable deduction would not be decreased. If this result is repugnant to the Commissioner and the courts, then the reporting of a constructive taxable income must be required. Calculation of this constructive figure will be even more difficult than calculation of constructive gross income, especially for miner-manufacturers who do not produce the representative product in their industry. How the difficulties can be overcome remains a problem.

\section{AMRNDMENT OF Section 613}

Before the Supreme Court's decision in the Cannelton case, the Commissioner had been notably unsuccessful in restricting the interpretation of "ordinary treatment process." He sought to circumvent the problem by securing amendment to the Code. ${ }^{38}$ The Treasury recommended that the troublesome phrase be replaced by a new definition of mining which would list the treatment processes includable in the depletion base for each mineral.

Finally, the week before the Supreme Court decided the Cannelton case, Congress enacted an amendment modeled on the Treasury's recommendations. ${ }^{39}$ It deleted the requirement of commercial marketability. It provided that the term "mining" include not merely the extraction of ores or minerals, but also "treatment processes considered as mining described in paragraph (4) (and the treatment processes necessary or incidental thereto)." 40

The parenthetic phrase, "and the treatment processes necessary and incidental thereto," may give rise to extensive litigation. At least two interpretations seem possible. The phrase may mean that a taxpayer can include not only the listed treatment processes but also processes further along toward the end product, which are "necessary and incidental" to the listed processes. This interpretation would permit the taxpayer to expand his depletion base

37 See note 9 supra.

38 See the Secretary of the Treasury's testimony in Hearings Before the House Committee on Ways and Means on General Revenue Revision, 85th Cong., 2d Sess., pt. 1, at 1097-98 (1958). President Eisenhower mentioned the Treasury's campaign in his budget message of January 18, 1960. New York Times, Jan. 19, 1960, p. 17.

39 P.L. 86-564, § 302(a), effective Jan. 1, 1961.

40 The Senate amendment did not include the phrase, "and the treatment processes necessary and incidental thereto." The phrase was a conference substitute. S. REP. No. 2005, 89th Cong., 2d Sess. (1960). 
beyond the limit set by the Cannelton case. But the phrase may mean only that the taxpayer may include in his depletion base certain processes which are supplemental to the listed processes, but which are not further along toward the end product. This interpretation would not permit expansion of the depletion base. Unless the courts give the new phrase the latter, restrictive interpretation, the Commissioner may find his efforts frustrated. The struggle is not yet over.

\section{SECURED LENDING AND SECTON 60(a) OF THE BANKRUPTCY} ACT: THE NEED FOR A UNIFORM TEST OF PERFECTION

In any appraisal of transactions giving rise to security interests in personal property, two fundamental elements must be considered. First, the device used must confer upon the secured creditor a priority interest in certain property against the risk of the debtor's insolvency or bankruptcy. Second, it must provide notice of the existence of the security interest to general creditors, either through transfer of possession of the collateral to the secured party or by some other feasible means.

Existing security devices, looked at against the background of the Bankruptcy Act, and particularly section 60 of that act, 1 are fulfilling neither of these aims effectively. Using accounts receivable financing as an example, this comment will discuss some typical problems that arise, and it will suggest that the most effective solution to the problem would be federal legislation in the form of an amendment to the Bankruptcy Act.

To understand the problems in this area it is essential to have some appreciation of the haphazard character of the growth of the various security devices, which has resulted in differences among them in rules, formalities, and requirements for perfection. 2 The oldest security device, dating back at least to Roman law, is the pledge. The essential element of a pledge is possession by the lender to secure payment of the obligation. Three currently used devices which represent a development of the pledge concept are the security interest of the carrier or warehouseman obtained by possession of a bill of lading or warehouse receipt; the pledge of stock certificates, bonds or debentures; and the field warehousing device.

But in many situations it is not possible or convenient to transfer possession of the collateral to the secured party so as to create a valid pledge. The chattel mortgage was developed to meet this situation. Naturally, where possession of the property remained with the debtor, some other means

130 Stat. 562 (1898), as amended, 11 U.S.C. $\$ 96$ (1958).

2 The brief discussion in the text of the history of security devices is adapted from Gilmore \& Axelrod, Chattel Security: I, 57 YaLE L.J. 517 (1948), and Gilmore, Chattel Security: II, 57 YALE L.J. 761 (1948). 